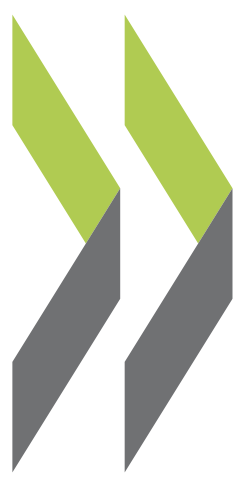

OECD Economics Department Working Papers No. 1184

Improving Health Outcomes Isabelle Joumard, and Health Care in India Ankit Kumar 
Organisation de Coopération et de Développement Économiques

Organisation for Economic Co-operation and Development

08-Jan-2015

ECONOMICS DEPARTMENT

English - Or. English

\section{IMPROVING HEALTH OUTCOMES AND HEALTH CARE IN INDIA}

ECONOMICS DEPARTMENT WORKING PAPERS No. 1184

By Isabelle Joumard and Ankit Kumar

OECD Working Papers should not be reported as representing the official views of the OECD or of its member countries. The opinions expressed and arguments employed are those of the author(s).

Authorised for publication by Robert Ford, Deputy Director, Country Studies Branch, Economics Department.

All Economics Department Working Papers are available through OECD's Internet website at http://www.oecd.org/eco/workingpapers 
OECD Working Papers should not be reported as representing the official views of the OECD or of its member countries. The opinions expressed and arguments employed are those of the author(s).

Working Papers describe preliminary results or research in progress by the author(s) and are published to stimulate discussion on a broad range of issues on which the OECD works.

Comments on Working Papers are welcomed, and may be sent to the Economics Department, OECD, 2 rue André-Pascal, 75775 Paris Cedex 16, France, or by e-mail to eco.contact@oecd.org.

This document and any map included herein are without prejudice to the status of or sovereignty over any territory, to the delimitation of international frontiers and boundaries and to the name of any territory, city or area.

The statistical data for Israel are supplied by and under the responsibility of the relevant Israeli authorities. The use of such data by the OECD is without prejudice to the status of the Golan Heights, East Jerusalem and Israeli settlements in the West Bank under the terms of international law.

\section{(C) OECD (2014)}

You can copy, download or print OECD content for your own use, and you can include excerpts from OECD publications, databases and multimedia products in your own documents, presentations, blogs, websites and teaching materials, provided that suitable acknowledgment of OECD as source and copyright owner is given. All requests for commercial use and translation rights should be submitted to rights@oecd.org 


\section{ABSTRACT/RÉSUMÉ \\ Improving health outcomes and health care in India}

With India's low life expectancy largely reflecting deaths from preventable diseases, the most significant gains in health would come from population-wide preventive measures. Access to public health care services varies substantially, resulting in many people turning to private-sector providers who mainly serve those who can pay. While government has scaled up public health services, more health professionals and public health care spending will be needed to ensure broad and adequate health-care coverage. Priority should be given to high impact primary health care services. For more resources to translate into better services, the management of public health care services needs to improve. The private sector can be drawn upon more extensively, but should also be obliged to meet basic quality standards.

This Working Paper relates to the 2014 OECD Economic Survey of India (http://www.oecd.org/eco/surveys/economic-survey-india.htm).

JEL classification: $H 51, I 13, I 15, I 18$

Keywords: India, health, public and private health insurance, health professionals, RSBY

\section{Améliorer la santé et l'accès aux soins de tous en Inde}

La faible espérance de vie en Inde s'expliquant largement par la mortalité liée à des maladies évitables, les gains les plus notables au plan sanitaire seront réalisés grâce à des mesures de prévention généralisées. L'accès aux services de santé publique est très variable et une part importante de la population se tourne vers les prestataires du secteur privé, qui servent essentiellement une population plus aisée. Si les autorités ont renforcé les services de santé publique, il faudra plus de professionnels de santé et plus de dépenses publiques de santé pour assurer une couverture sanitaire adéquate. Il conviendrait de donner la priorité aux services de soins primaires, à fort impact. Il conviendrait également d'améliorer la gestion des services publics de santé pour garantir une meilleure qualité de ces services par rapport aux ressources investies. Le secteur privé pourrait être davantage mis à contribution, mais devrait également être tenu de respecter des normes de qualité minimales.

Ce Document de travail se rapporte à l'Étude économique de l'OCDE de l'Inde, 2014 (http://www.oecd.org/fr/eco/etudes/inde.htm).

Classification JEL : H51, I13, I15, I18

Mots clefs : Inde, santé, assurance santé publique, assurance sante privée, professionnels de santé, RSBY 


\section{TABLE OF CONTENTS}

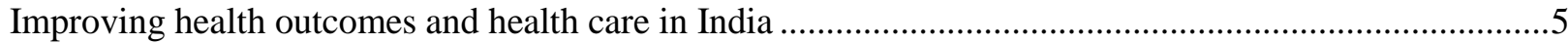

The largest gains in health status will come from preventive measures ...................................................5

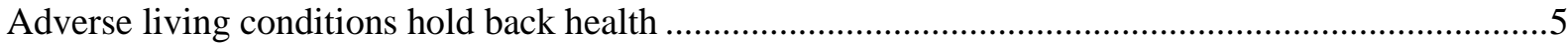

Improving living conditions and lifestyle habits would have the greatest impact .................................

Access to health care services should be expanded and the quality of care improved ................................8

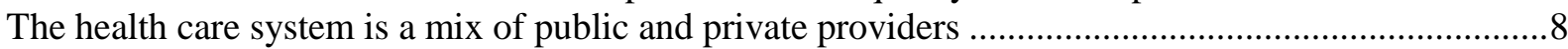

More and better educated health professionals are required to improve access to health care ..............11

Better use of drugs would improve the quality of health care and reduce out-of-pocket payments ......15

Devoting more public funds to health care and improving the effectiveness of spending .......................16

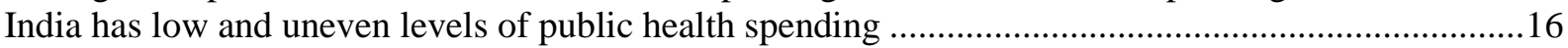

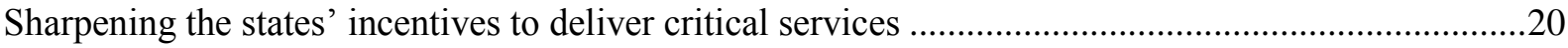

Extending the coverage of government-sponsored insurance schemes.............................................21

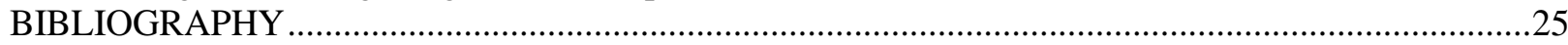

\section{Tables}

1. Few households declare having access to free or partially-free health care from the government ......9

2. Key health workforce indicators for the 18 most populous states ................................................13

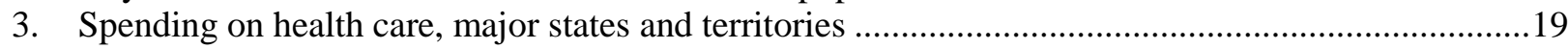

4. Major government-sponsored health insurance schemes: eligibility and coverage ..........................23

\section{Figures}

1. Life expectancy has improved but remains behind most other emerging economies ........................6

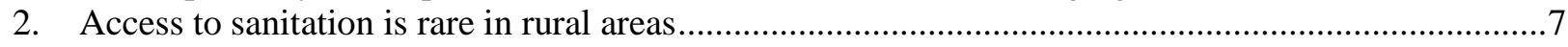

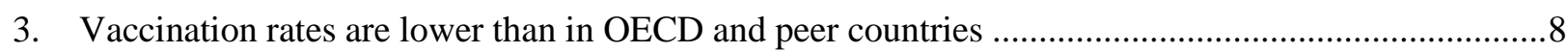

4. India spends less on health care than other middle-income countries ...........................................11

5. India spends less on health care than other middle-income countries ..........................................17

\section{Boxes}

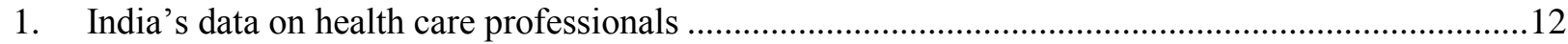

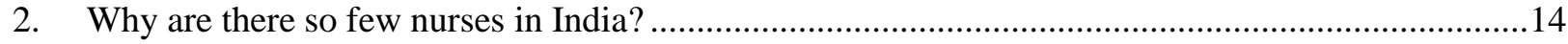

3. The challenge of making health a priority in a decentralised setting ..............................................18

4. The National Rural Health Mission ..........................................................................................19

5. Financing expansion in health in a federal context: Mexico's Seguro Popular ...............................21

6. The RSBY facilitates access to hospital care for the poor .............................................................22

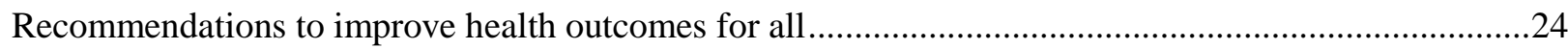




\title{
Improving health outcomes and health care in India
}

\author{
By Isabelle Joumard and Ankit Kumar ${ }^{1}$
}

\begin{abstract}
Despite large improvements in recent years, life expectancy in India remains below countries at a similar level of development. Health outcomes and service provision vary significantly across states, with only a few providing access to comprehensive basic health care services to everyone. Although public health care in principle offers free basic health care services to all, most states' health systems suffer from insufficient spending and shortfalls in management, leaving many with insufficient care. As a result, most people turn to private health care providers, which vary dramatically in quality and charge for their services.
\end{abstract}

\section{The largest gains in health status will come from preventive measures}

\section{Adverse living conditions hold back health}

Life expectancy at birth has increased from 49.1 years in 1970 to 66.3 years in 2012, a larger gain than in China and Brazil (Figure 1). Public health efforts over past decades have contributed to these improvements, as most recently demonstrated through the recent eradication of polio after an ambitious immunisation campaign. Nevertheless, life expectancy and other health status indicators remain behind most large middle income countries and health outcomes are strongly influenced by socio-economic factors, gender, education and geography (Balarajan et al. 2011; Raj, 2011).

Life expectancy is low due to a high proportion of deaths from communicable diseases, particularly among the young. While infant mortality has halved since 1990, it is still high when compared to most other emerging economies. These young deaths largely reflect preventable situations such as pre-term birth complications, lower respiratory infections (such as pneumonia) and diarrheal diseases, which together accounted for $21 \%$ of potential years of life lost due to ill health (IHME, 2013).

Compounding the high number of young deaths is the lifetime consequences of poor nutrition among poor mothers and their children. By retarding physical and mental development, malnutrition reduces a potential health later in life, as stunted and anaemic children suffer from fewer years of schooling, reduced productivity and lower incomes as adults (Spence and Lewis, 2009). India has higher proportions of low birth weight children and nutrient deficiencies compared with other South Asian countries, China and even sub-Saharan Africa in some cases (Drèze and Sen, 2013).

1. Isabelle Joumard is Head of the India Desk in the Economics Department of the OECD while Ankit Kumar was a policy analyst in the Health Division at the time of writing. This paper is based on material prepared for the OECD Economic Survey of India published in November 2014 under the authority of the Economic and Development Review Committee (EDRC). The authors would like to thank Francesca Colombo, Robert Ford, Mark Pearson, Alvaro Pereira and Piritta Sorsa for valuable comments on earlier drafts. Special thanks go to Anthony Bolton and Annamaria Tuske for technical preparation. 
Figure 1. The population health status has improved but remains behind most other emerging economies
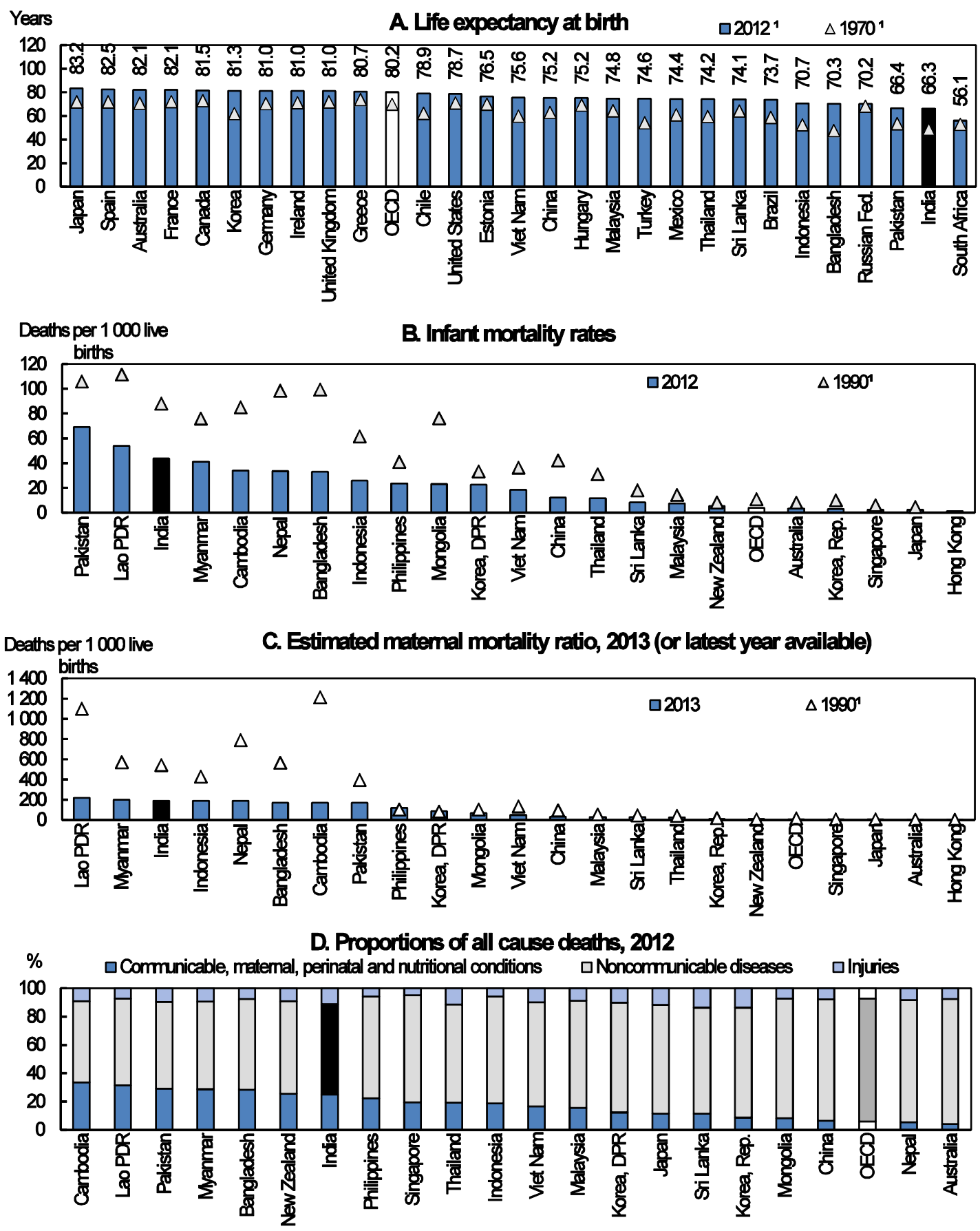

1. Or nearest available year.

Source: OECD (2014), Health Database; World Bank, World Development Indicators Database; UN Inter-agency Group for Child Mortality Estimation (IGME) Childinfo; UN Demographic Yearbooks; Statistics and Census Service, Macao, China, 2014 ; and WHO. 
Chronic diseases are the biggest causes of death and disability, as in most OECD countries. They accounted for $50 \%$ of deaths, with cardiovascular diseases and diabetes, respiratory conditions and cancers figuring most prominently (Patel et al, 2011). India has low rates of daily smoking, though many of the poor smoke heavily. Obesity rates are relatively low, but $11 \%$ of the lowest income quintile did not undertake sufficient physical activity, compared with 16\% in the highest income quintile (OECD, 2012a). Exposure to air pollution is a significant problem. The burning of solid fuels in particular (undertaken by more than $80 \%$ of the population in cooking) is a major risk factor behind ischemic heart disease, lower respiratory infections and chronic obstructive pulmonary diseases (IHME, 2013) and it could increase cataracts and stroke.

\section{Improving living conditions and lifestyle habits would have the greatest impact}

With poor health intertwined with poverty, the greatest gains lie with policies that address the social conditions which enable combating communicable diseases. Most households in rural areas do not defecate in a toilet or latrine (Figure 2), which leads to infant and child diseases (such as diarrhoea) and can account for much of the variation in average child height. The Total Sanitation Campaign, which constructs low cost pit latrines in rural areas, has been a highly effective way of reducing young deaths and reducing a range of developmental disorders later in life (Spears and Lamba, 2013). The Swatchh Bharat Abhiyan programme (Campaign Clean India) launched in October 2014 aims at providing every household with access to sanitation by 2019 and is a welcome initiative. Similarly, preventive interventions such as improving access to a clean water supply, reducing the spread of HIV/AIDS through better sexual education, and vaccination campaigns for other diseases will each deliver more significant returns in life years saved across the population than many of the services delivered by hospitals today (Chow et al, 2007). Vaccination rates for diphtheria, tetanus and pertussis, for measles and for hepatitis B are all much lower than in OECD and peer countries (Figure 3).

Figure 2. Access to sanitation is rare in rural areas

Rural population with access to improved sanitation

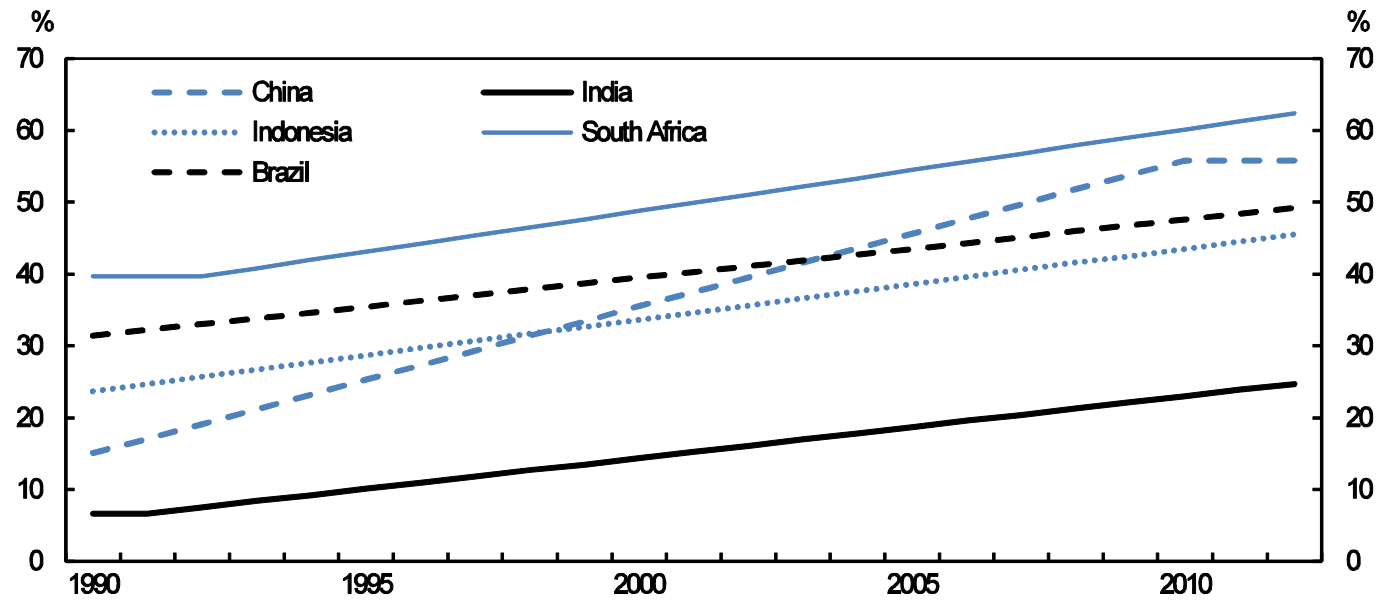

Source: WHO (2014), Public Health and Environment Database. 
Figure 3. Vaccination rates are lower than in OECD and peer countries
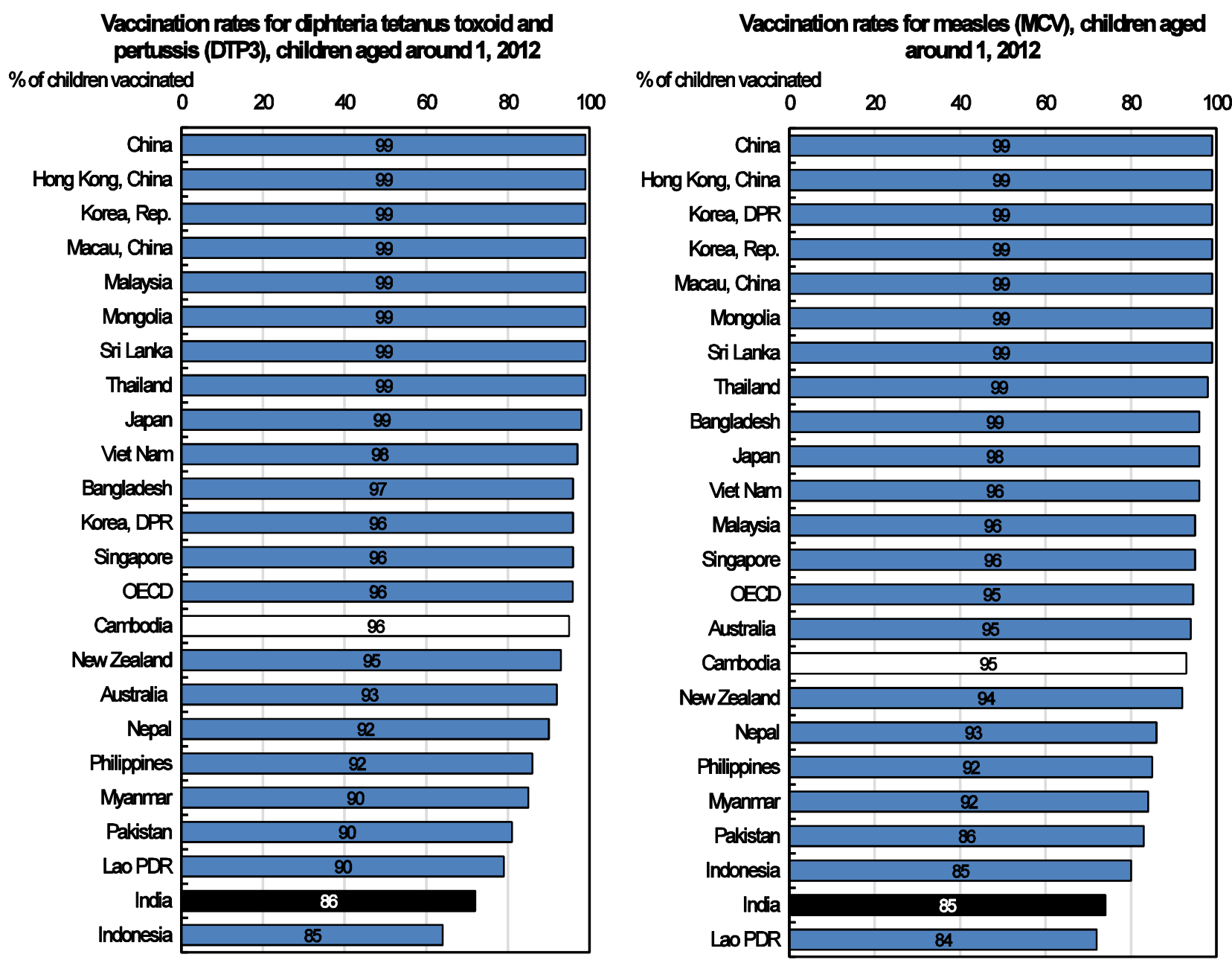

Source: WHO, Global Health Observatory 2014.

Policies targeted at chronic diseases are also highly cost-effective. Bringing the taxation of bidis (small hand rolled cigarettes which account for $70 \%$ of tobacco smoked in India) in line with that of cigarettes, reducing dietary salt intake, eyesight screening, improving road safety and enforcing taxation on illicit alcohol production should all be priority areas for action (Patel et al, 2011). While the focus of governments are often on health facilities, it is important not to lose sight that broad based efforts to tackle poor living and lifestyle habits are where the largest gains to health lie.

\section{Access to health care services should be expanded and the quality of care improved}

\section{The health care system is a mix of public and private providers}

India's national health care system aspires to provide a comprehensive array of services to all and at no cost, but struggles to do so in practice. Public health care services - clinics in the community which deliver basic front line health care services, regional hospitals and tertiary hospitals that can provide highly specialised procedures in cities - are funded by states and the federal government and run by state governments. Health care practitioners are employed as civil servants and assigned to facilities. 
One study showed that only $16 \%$ of the population declares that their household has access to free or partially free public health care. Although this share is higher in the lowest income bracket, this share rises with income after the third income bracket (Table 1) suggesting that public spending on health care contributes less than it should to reduce inequality in living standards. Free care is more frequent for hospital visits than for vaccinations and prescriptions.

Table 1 Few households declare having access to free or partially-free health care from the government

$\%$ of surveyed people responding "yes" to the question "Does your household have access to free or partially free health care from the State" by income bracket ${ }^{1}$

\begin{tabular}{lccccccccccc}
\hline & $\mathbf{1}$ & $\mathbf{2}$ & $\mathbf{3}$ & $\mathbf{4}$ & $\mathbf{5}$ & $\mathbf{6}$ & $\mathbf{7}$ & $\mathbf{8}$ & $\mathbf{9}$ & $\mathbf{1 0}$ & Total \\
\hline India & 29 & 13 & 10 & 14 & 13 & 18 & 23 & 23 & 20 & & 16 \\
Brazil & 38 & 8 & 18 & 20 & 23 & 33 & 34 & 43 & 58 & & 24 \\
China & 59 & 71 & 69 & 70 & 75 & 70 & 68 & 79 & 79 & 78 & 73 \\
Indonesia & 48 & 57 & 59 & 58 & 55 & 63 & 65 & 44 & 67 & & 57 \\
Mexico & 66 & 68 & 70 & 71 & 78 & 77 & 43 & & & 68 \\
Russia & 100 & 97 & 97 & 98 & 95 & 99 & 98 & 98 & 100 & 100 & 96 \\
South Africa & 64 & 76 & 70 & 76 & 67 & 63 & 51 & 42 & 40 & 25 & 62 \\
\hline
\end{tabular}

1. Approximately 1500 respondents were surveyed in each country, with India and China both having larger sample size of 2500 .

The male-to-female split between respondents was roughly 50:50 in all cases with rural-to-urban split varying by country.

Source: Credit Suisse Research Institute, Emerging Consumer Survey Databook 2014.

\section{Public health care services differ substantially between states}

The quality of public health care providers varies significantly across states and between rural and urban areas. In a few states, such as Tamil Nadu and Kerala, public health facilities play their intended role of being the first point of care and proactively delivering essential services. They are reliably open (often for 24 hours a day), well stocked with critical medicines and supplies, and staffed by trained professionals. At the other end of the spectrum, a handful of world-class public sector tertiary hospitals (i.e. hospitals providing sophisticated care facilities), such as the All India Institute of Medical Sciences, are often a model for OECD countries on innovation in delivering health care at low costs.

Beyond a select few states and pockets of excellence, the public sector is falling short of its objective of meeting the basic health care needs of the population. Services are often too far away, lacking trained personnel and supplies, and not reliably open. Surveys indicate that $41 \%$ of those in rural areas and $45 \%$ in urban areas were not satisfied with treatment by their doctor or facility. Distance was cited by $21 \%$ of people in rural areas and 14\% in urban areas and the non-availability of services was cited by $30 \%$ of people in rural areas and 26\% in urban areas (Kumar et al, 2011). Though national surveys are based on self-reporting and may be subject to biases, their results are reinforced by government estimates that $10 \%$ of primary health care centres are without a doctor, $37 \%$ are without a laboratory technician and $25 \%$ without a pharmacist (MoHFW, 2012). This picture is consistent with large scale trials in poor communities, which found that public health care centres were closed more than half the time and lack basic medical supplies, such as stethoscopes and blood pressure scales. In many instances, however, public facilities are the only source of qualified health professionals in rural areas where much of the poor live. At the same time, significant population growth is occurring in urban slums. Urban public health care facilities are struggling to provide basic services and slum dwellers face economic and educational barriers to accessing private care (MoHFW, 2012).

Poor management is a particular challenge in public services. The public health care systems of Tamil Nadu and Kerala have demonstrated both consistently better public health outcomes and average (or lower 
than average) levels of per capita public health spending. What distinguishes these states is that they have maintained a political commitment to delivering primary care over several decades, in many cases prioritising these services ahead of hospitals. Underpinning this has been dedicated training for the managers of primary health centres and district hospitals (Muraleedharan et al., 2013). Similarly, the higher performing states of Andhra Pradesh, Gujarat and Madhya Pradesh each require their public health sector managers to undertake specific training on communicable diseases and risk factors (HLEG, 2011). These best practice examples ought to be the norm, and more efforts are needed in state governments across the country. In addition, the frequent rotation of key civil servants should be reduced for the health sector, to allow for system managers to be held accountable for policies which often have long time lags.

\section{A vast array of private health care services fills the void left by public services}

With shortfalls in public services, private health care services have grown rapidly to meet rising expectations and incomes. Private health care providers dominate service provision today, although data are poor. Surveys indicate that public facilities provided only $20 \%$ of primary and community-based health care services, and $40 \%$ of hospital visits in $2004-05$, down from $25 \%$ and $60 \%$ respectively in 1986-87. Measured by the availability of resources, available estimates (albeit from 2002) indicate that $75 \%$ of human resources and advanced medical technology and $68 \%$ of hospitals are provided by the private sector (NCHM, 2005). Around $90 \%$ of dentists and $80 \%$ of practitioners of ayurveda, yoga and naturopathy, unani, siddha and homeopathy (AYUSH) are also in the private sector. Nurses are more evenly distributed, with half the number of nurses and midwives in the public sector. Unfortunately, alongside these qualified professions exist unskilled persons falsely practising as doctors (Rao et al., 2011).

At the high end of the market, the private sector has world class facilities. Taking advantage of comparatively low labour costs, 'five-star' hospitals, which have facilities comparable to the most advanced hospitals in OECD countries, have grown substantially. As a result, hospital care has emerged as an export sector, with estimates suggesting that revenues for medical tourism were USD 2 billion in 2012 and that India cares for around 200000 foreign patients a year (Lunt et al, 2010).

Until recently, neither state nor federal governments have played a major role in financing or regulating private health care services. For these services, access is rationed on the ability to pay and their quality is uneven. With few barriers to entry and quality regulation that is barely enforced or is limited to a small number of high end hospitals, a large number of private facilities are delivering services without the equipment and expertise for their work. A survey of 24 private hospitals in Mumbai found half of them to be operating in lofts, congested spaces or have leaks in their operating theatres (Nandraj et al, 2001). Corruption and inappropriate clinical practices are also a concern, with doctors receiving payments from drug companies and medical supplies manufacturers (Sachan, 2013).

There are considerable problems of unqualified nurses and doctors working in private facilities. There have been few efforts to develop regulations to ensure that workers have the appropriate medical education or demonstrating that basic standards of cleanliness and safety are being adhered to. Where such regulation exists for health professionals, it is poorly enforced. All OECD countries have systems to help patients and employers verify a doctor's specialisation and expertise. These are operated by medical associations, which undertake this role to safeguard the reputation of the profession with employers and consumers. If the Medical Council of India cannot fulfil this role, the government should step in and do so, as has been the case in Israel.

Where standards for private hospitals currently exist, they are currently poorly enforced. The 2010 Clinical Establishments Act is a long overdue response but the legislation is being implemented slowly and has not been adopted by all states. While India's most sophisticated private sector hospitals have sought to have themselves accredited against world's best standards, a basic model of accreditation suitable for all public and private hospitals should be developed. 


\section{More and better educated health professionals are required to improve access to health care}

A major constraint on efforts to improve access to health care services is the low levels of qualified health personnel (Figure 4) and their uneven geographical distribution. Recent research suggests government figures may be over-estimated as they include people who identify themselves as a doctor or nurse but are not qualified (Box 1).

Figure 4. India spends less on health care than other middle-income countries
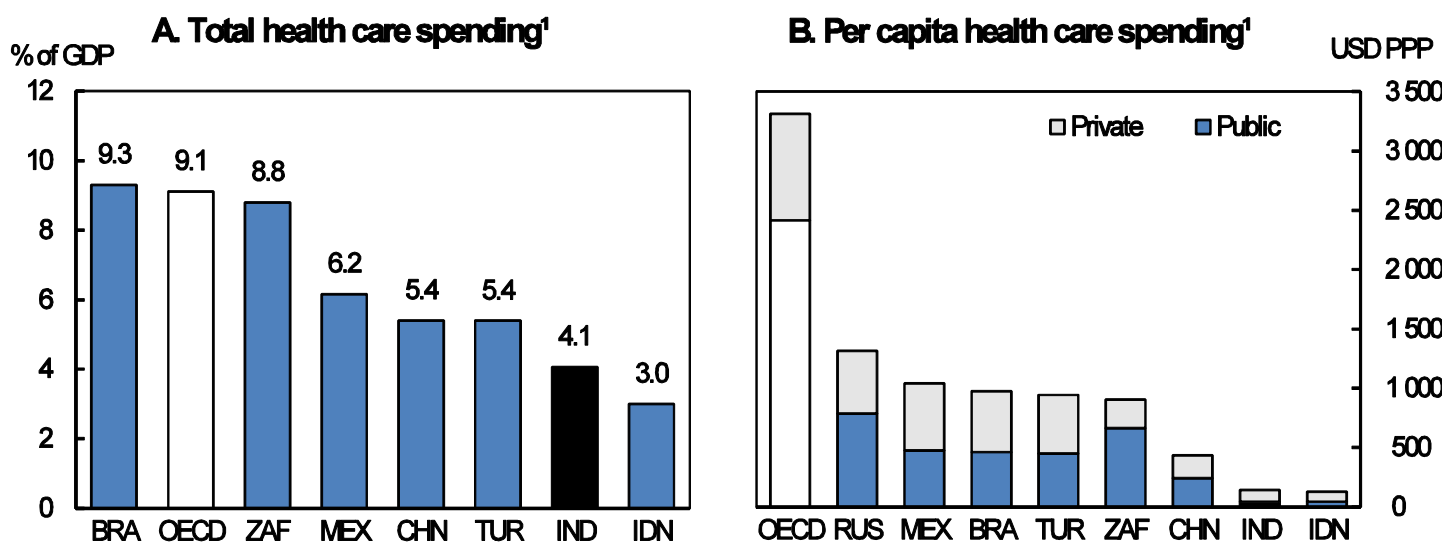

\section{Composition of health spending}

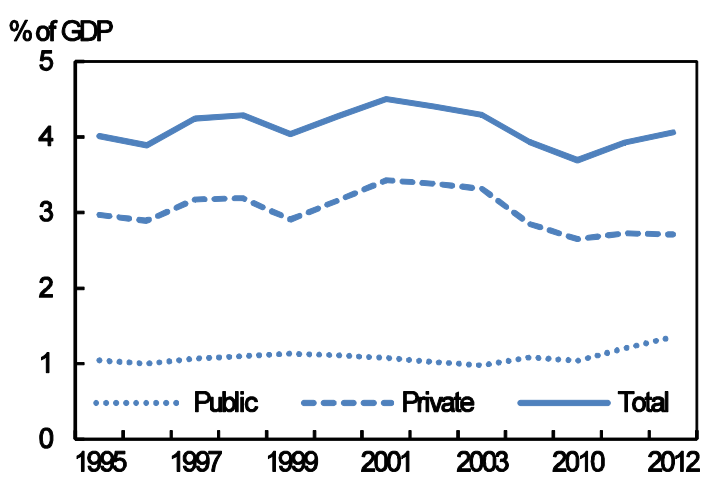

\section{Share of health care in total} government spending'

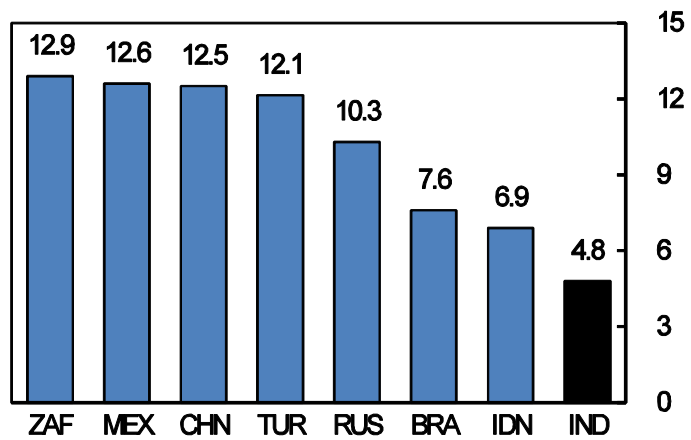

1. Data refer to 2012 or latest available year.

Source: OECD (2014), Health Database; WHO (2014), Health Systems Database. 


\section{Box 1. India's data on health care professionals}

Data on health care professionals in India should be interpreted with caution. Both OECD and WHO data are based on government reports which draw information from the state-level registers of professional bodies (e.g. the medical council and nursing councils). These registers are not frequently updated. Furthermore, other types of health professionals often do not have a council (e.g. physiotherapists and lab technicians). Alternative estimates can be drawn from the Census and household surveys conducted by the National Sample Survey Organisation, however these rely on self-reporting of occupation, with no verification of actual credentials.

In most OECD countries, 'physicians' are persons who have completed studies in medicine at a university level and who are licensed to practice (generally by a professional body). In India, many people identify themselves as physicians even though they do not have a medical degree. One study found that $37 \%$ of physicians (63\% in rural areas and $20 \%$ in urban areas) had inadequate or no medical training (Rao et al. 2012). Another study quoted by Rao et al. (2011) found that $25 \%$ of those who called themselves allopathic doctors had no technical degree, diploma or certificate in medicine.

By drawing on multiple sources and adjusting health worker figures with educational qualification, Rao et al. (2012) estimate that:

- the number of doctors may be closer to 0.38 per 1,000 population rather than official estimates which range from 0.70 to 0.65 per 1,000 population;

- the total number of health workers is 0.8 per 1000 population, rather than the 2 per 1000 population reported in the census - this broad measure counts nurses, midwives, ayurvedic health workers, dentists and pharmacists alongside doctors;

- there are 0.12 doctors in rural areas compared to 1.13 doctors per 1000 population in urban areas, reflecting that rural areas have both a larger population and a higher proportion of health professionals reporting insufficient qualifications.

These revised estimates of health workers place India considerably lower than the average of 1.2 physicians per 1000 people in developing countries in East Asia and the Pacific. For nurses and midwives, India places below the 0.8 per 1000 population observed in Sub-Saharan Africa, though these countries are also likely to suffer from data issues (World Bank, 2013a). This situation highlights the need for functional and current medical registries, not only to guide public policy but also to help patients and employers distinguish between qualified and unqualified practitioners.

A striking feature is the large number of people with training in traditional medicine working alongside doctors and nurses. Government figures suggest some 0.6 workers per 1000 people are trained in one of Ayurveda, Yoga and naturopathy, Unani, Siddha or Homeopathy (known as 'AYUSH' workers), and have benefited from formal education in these alternative therapies. Many public facilities rely on these workers to staff primary health care clinics, particularly in rural areas. A large number of informal workers are often the first point of contact for the poor in rural areas. These include traditional birth attendants, herbalists, snake-bite curers and bone setters. These workers have no professional qualification or licence to practice, but some have been reported to work with doctors, laboratories and hospitals to refer patients in exchange for commissions (Rao et al, 2011).

\section{Shortages are most acute in the populous and rural states of the north}

There is substantial variation in the numbers of health workers across states. Populous and rural states of the north suffer most from the lack of doctors and nurses (Table 2). There is a strong association between health workforce density and delivery of basic public health services such as measles immunisation, greater attended deliveries and lower infant mortality, with the effect of workforce density in improving these key outcomes appearing to peak at around 2 to 3 doctors, nurses and midwives per 1000 people (Rao et al., 2012). 
ECO/WKP(2015)2

Table 2 Key health workforce indicators for the 18 most populous states

\begin{tabular}{|c|c|c|c|c|c|c|}
\hline States $^{1}$ & $\begin{array}{c}\text { Health } \\
\text { workers (per } \\
\text { 1000) }\end{array}$ & $\begin{array}{c}\text { Doctors (per } \\
1000)\end{array}$ & $\begin{array}{c}\text { Nurses (per } \\
1000)\end{array}$ & $\begin{array}{l}\text { Population } \\
\text { (\% of total } \\
\text { population) }\end{array}$ & $\begin{array}{c}\begin{array}{c}\text { Rural } \\
\text { population } \\
(\%)\end{array} \\
\text { (\%) }\end{array}$ & $\begin{array}{l}\% \text { births attended } \\
\text { by skilled } \\
\text { personnel }\end{array}$ \\
\hline Andhra Pradesh & 2.1 & 0.8 & 0.8 & 7 & 67 & 69 \\
\hline Assam & 1.4 & 0.3 & 0.6 & 3 & 86 & 33 \\
\hline Bihar & 1.0 & 0.4 & 0.3 & 9 & 89 & 30 \\
\hline Chhattisgarh & 1.6 & 0.4 & 0.6 & 2 & 77 & 29 \\
\hline Delhi & 4.5 & 1.5 & 1.5 & 1 & 0 & 60 \\
\hline Gujarat & 1.7 & 0.4 & 0.6 & 5 & 57 & 62 \\
\hline Haryana & 2.0 & 0.8 & 0.5 & 2 & 65 & 43 \\
\hline Jharkhand & 1.4 & 0.4 & 0.6 & 3 & 76 & 28 \\
\hline Karnataka & 2.1 & 0.7 & 0.8 & 5 & 61 & 67 \\
\hline Kerala & 3.8 & 0.6 & 1.9 & 3 & 52 & 98 \\
\hline Madhya Pradesh & 1.6 & 0.5 & 0.6 & 6 & 72 & 36 \\
\hline Maharashtra & 2.9 & 0.8 & 1.1 & 9 & 55 & 63 \\
\hline Orissa & 2.0 & 0.3 & 1.3 & 3 & 83 & 44 \\
\hline Punjab & 2.7 & 1.1 & 0.8 & 2 & 63 & 64 \\
\hline Rajasthan & 1.4 & 0.4 & 0.5 & 6 & 75 & 44 \\
\hline Tamil Nadu & 2.3 & 0.6 & 1.0 & 6 & 52 & 89 \\
\hline Uttar Pradesh & 1.3 & 0.6 & 0.3 & 16 & 78 & 29 \\
\hline West Bengal & 2.4 & 0.7 & 1.0 & 8 & 68 & 54 \\
\hline India & 1.9 & 0.6 & 0.7 & & 69 & 48 \\
\hline
\end{tabular}

1. States are ordered by alphabetic order.

Source: Rao et al (2008), MOSPI (2013) and DLHS (2006)

Among health professionals, the shortage of nurses is the most critical as they often provide many basic health services to the poor (Box 2). With only one nurse per doctor, this shortage is particularly severe compared to OECD and middle income countries, where nurses generally outnumber physicians. India is a poor performer on health services which in other countries are provided by nurses - awareness of health or public health programmes, immunisation, safe deliveries, antenatal checks and basic data collection (BMJ, 2013). A review of Tamil Nadu's success at achieving improved health outcomes at lower costs highlights that it deployed 'Village Health Nurses' in rural communities earlier than other parts of India (Muraleedharan et al, 2013). Data from rural primary health care facilities where these services are normally delivered indicate that there was a shortfall of $55 \%$ of the required number of basic nurses. The shortage of nurses places considerable demands on doctors, when their higher unit cost of labour is better deployed in undertaking diagnosis and dealing with complex patients. It also results in AYUSH workers facing pressure to deliver medical care that may be beyond the scope of their training.

Given the critical role of women in specific health care services (e.g. sexual health, decisions about birth and the early years of a child's life), a particular challenge is that nearly two-thirds of health workers are men. This is particularly the case among doctors, where only $17 \%$ are women (6\% in rural areas). However, $70 \%$ of nurses are women, in part reflecting the social perception that caring for others is a vocation for women from middle and lower socio-economic backgrounds. 


\section{Box 2. Why are there so few nurses in India?}

It has been estimated that some $40 \%$ of nurses registered in March 2003 were inactive because of recruitment issues, migration, attrition and drop-outs from poor working conditions (Malik, 2008). At the same time, successive reports monitoring the rollout of the National Rural Health Mission have identified shortages in nursing staff.

A particular social challenge is that frequent contact to polluting substances (blood, feces, vomit, etc) and sensitivities about receiving care from those of different castes dissuade many but the poorest of the dominant Hindu population to consider a career in nursing. This is reflected in the traditional over-representation of nursing by Christians, who account for the majority of India's nurses, and explains the dominance of the states of Kerala and Goa in nursing education. These two states account for $40 \%$ of the country's nursing schools.

At the same time, for women from lower income backgrounds, nursing provides opportunities to readily seek opportunities outside of India, where incomes earned by women may provide them with agency in addressing traditional expectations associated of marriage, dowry and motherhood. A study conducted in Gulf countries found that half of Indian migrants to these countries were from Kerala, among which nurses are roughly estimated to account for between $27-40 \%$ of all females. Among this subset, $90 \%$ were of Christian origin. With two generations of migration from Kerala to the Gulf, this has become a well-established path to migration to other OECD countries, with women often seeking to balance their individual motives to support their family back at home and gain further professional independence than may have been available to them in India.

Sources: Malik (2008) and Percot (2006)

\section{Increasing the number of qualified health professionals, particularly in northern states}

To address the shortfall of health care professionals, the incoming government plans to establish elite medical training schools (All India Institute of Medical Sciences) in every state. Expanding the number of graduates should also be a priority. The deregulation of medical education and the expansion in the number of private colleges over past years has greatly helped expand capacity. However, it has also raised considerable concerns about the quality of education (Rao et al, 2012). Establishing quality assurance for medical training and ensuring that education costs are not too high will be critical to securing a pipeline of well-trained doctors and nurses. In addition, a critical step to guide policy is to build a database of India's human resources for health, covering the types of health workers, where they are located and their employment conditions (Rao et al, 2011), as is the norm in the majority of OECD countries.

The central government should use its powers to determine where medical colleges are located to redress geographical shortages in northern and poorer states. Today, states in South India are home to 52\% of the country's nursing schools, while the north, west, east, and north east have $31 \%, 8 \%, 7 \%$, and $2 \%$ respectively (Bhaumik, 2013). Similarly, the south-western states of Andhra Pradesh, Maharashtra, Karnataka, Kerala and Tamil Nadu accounted for 58\% of all medical colleges, while populous states with poor health have only $15 \%$ of all medical colleges. Making the most of their advantage, states with more colleges offer direct career pathways for doctors and nurses into their public health services. The establishment of six new All India Institutes of Medical Sciences in areas with low numbers of health professionals is a positive step in this direction, though efforts will be needed to get students to stay in these areas after their education.

Medical training should require experience in rural communities and in primary care. Recent OECD research suggests that small financial incentives have not been effective in encouraging doctors and nurses to move to more deprived and rural areas. Regulatory policies, such as obliging rural service or developing rural medical schools, are more effective (Ono et al, 2014). Australia and Canada use medical education to give students greater experience of work in rural communities. Some Indian states oblige medical students to practice in a rural area as part of their clinical education - e.g. Tamil Nadu reserves a share of 
postgraduate education posts for those who have worked in government facilities. While these regulations have been unpopular with students, the high level of public subsidy, significant personal returns to medical education and the weak recruitment of graduates into public hospitals justify the adoption of such compulsive approaches. Similarly, governments and colleges should seek to incorporate a rotation in a primary health care facility into medical education. At a clinical level, this provides young doctors with generalist skills and greater exposure to the range of conditions afflicting the population.

Together with better local infrastructure, implementing a shorter 'rural medical degree' could help bring new doctors into the system to address the needs of under-served communities. The establishment of the new three year Bachelor of Community Health by the central government is a welcome step in this direction. Similarly, government should consider offering AYUSH workers the opportunity to undertake a 'bridging' rural medical or advanced nursing degree, as has been pioneered in Tamil Nadu and Maharashtra, to provide higher incomes and career development opportunities to those who have already demonstrated a commitment to health services. This would also recognise the reality that in rural and poor communities patients already turn to these workers for basic medical services (Chandra, 2012).

Greatest attention is needed to encourage more nurses to join and stay in the health workforce. Government 'stipends' provide an income that help attract women from lower socio-economic backgrounds to study nursing, but many of the most qualified nursing graduates choose to emigrate after completing their studies. Better job contracts ought to be considered, as nurses generally face greater shortterm contracts. Similarly, those working as assistants to nurses (known as 'auxiliary nurse midwifes' and 'lady health visitors') with minimal levels of training, ought to be given the possibility of undertaking a nursing diploma (Raha et al, 2009). The new 'Continuing Nursing Education Programme' is a positive development in this regard. The government should also seek to encourage the development of nurses with expert medical skills in a select area (known as advanced professional nurses), as exist in Canada, Ireland and the United States today (OECD, 2010). This would provide opportunities for career advancement that might help dissuade nurses from leaving for overseas.

Efforts should also be made to improve working conditions and career prospects for health care professionals, especially those in rural communities. The central government should seek to understand wage differences across states and also between the public and private sectors. Research finds that concerns over personal security, poor community infrastructure, limited schooling options and less career progression count among the factors dissuading doctors from practising in rural areas (Rao et al, 2012). In 2000, India was the single most important origin country for doctors migrating to OECD countries and ranked $6^{\text {th }}$ for nurses $(\mathrm{OECD}, 2007)$. Although migration may deprive India from well-trained doctors and nurses, its impact should be evaluated by also taking into account the duration of stay. On the positive side, some of those who settle abroad may eventually come back and work in India, with more expertise and knowledge of different techniques.

\section{Better use of drugs would improve the quality of health care and reduce out-of-pocket payments}

India is able to procure medicines at lower unit prices than other low and middle income countries (WHO/HAI, 2006), which suggests drug affordability ought to be less of an issue. However, spending on drugs is the single largest component of household out-of-pocket (OOP) payments, and accounts for about three-fourths of all OOP spending for the poor (Selvaraj and Karan, 2012). OOP payments on drugs are high because essential medicines are often out of stock in public hospitals where they are supposed to be provided for free or at a very low price, and because of inappropriate drug prescriptions in the private sector. The median availability of a sample of key generic medicines in public sector facilities was $22 \%$ compared to $77 \%$ in the private sector facilities (WHO, 2012). This partly reflects the lack of efficient supply chain management and a weak drug procurement process. The Medical Store Depots, from which various public hospitals order drugs, are under no obligation to stock generic alternatives, they generally 
lack quality controls and corruption is often an issue (Shepherd-Smith, 2012). The introduction of a centralised procurement system in the state of Tamil Nadu has resulted in a drop in drug prices and increased drug availability in public health care facilities.

As a result of shortages in the public sector, patients turn to the private sector, where the distribution and sale of drugs is poorly regulated. A large number of studies have found inappropriately high levels of prescribing by doctors, nurses and pharmacists (especially in rural areas), high levels of self-medication and weak controls on the sale of prescription drugs (Das et al. 2006; Kotwani, 2010; Ray et al. 2003). Firms engage in aggressive marketing tactics, such as providing expensive gifts and targeting health workers in small towns in particular (Roy et al. 2007 and Kripalani 2008). While government attempts to regulate the prices of a select group of medicines, as in other OECD countries, the margins between manufacturer sale prices and those paid by consumers can be as high as $300 \%$, well above the legislated level of $20 \%$ (NPPA, 2002).

Spending on drugs can be reduced and the quality of care improved by better prescribing practices and enforcement of existing laws and regulations on drug sales. By actively training health workers on how to appropriately prescribe drugs, Delhi has achieved savings of around 35\% on annual drug spending (Chaudhury et al., 2005). A best practice model in the OECD in this regard is Australia's National Prescribing Service, which provides health workers with information about the appropriate use of medicines.

\section{Devoting more public funds to health care and improving the effectiveness of spending}

\section{India has low and uneven levels of public health spending}

India spends less on health care than other middle income countries. At 4\% of GDP in 2012, spending on health care was half that of Brazil and South Africa, and much lower than China (Figure 5, Panel A). When measured in per capita terms (Figure 5, Panel B), India is $184^{\text {th }}$ out of 191 countries in public spending on health. Government (central, state and local) was the source of about one-third of spending while out-of-pocket payments represented about $58 \%$ - one of the highest percentages in the world. As a share of total public spending, health is also low (Figure 5, Panel D). In addition, this money is not often spent well. A study by Transparency International in 2008 suggests that the health sector was the second most corrupt in India (Sudarshan and Prashanth, 2011).

The consequence of low levels of public spending and poor access to public facilities is that households bear the cost of services in the private sector. Some cannot access health care while others fall into poverty as a result of health spending. Among those people that did not access care for a short-term health condition in India, $28 \%$ of those in rural areas said it was due to financial problems, compared to $20 \%$ in urban areas (NSSO, 2006). 


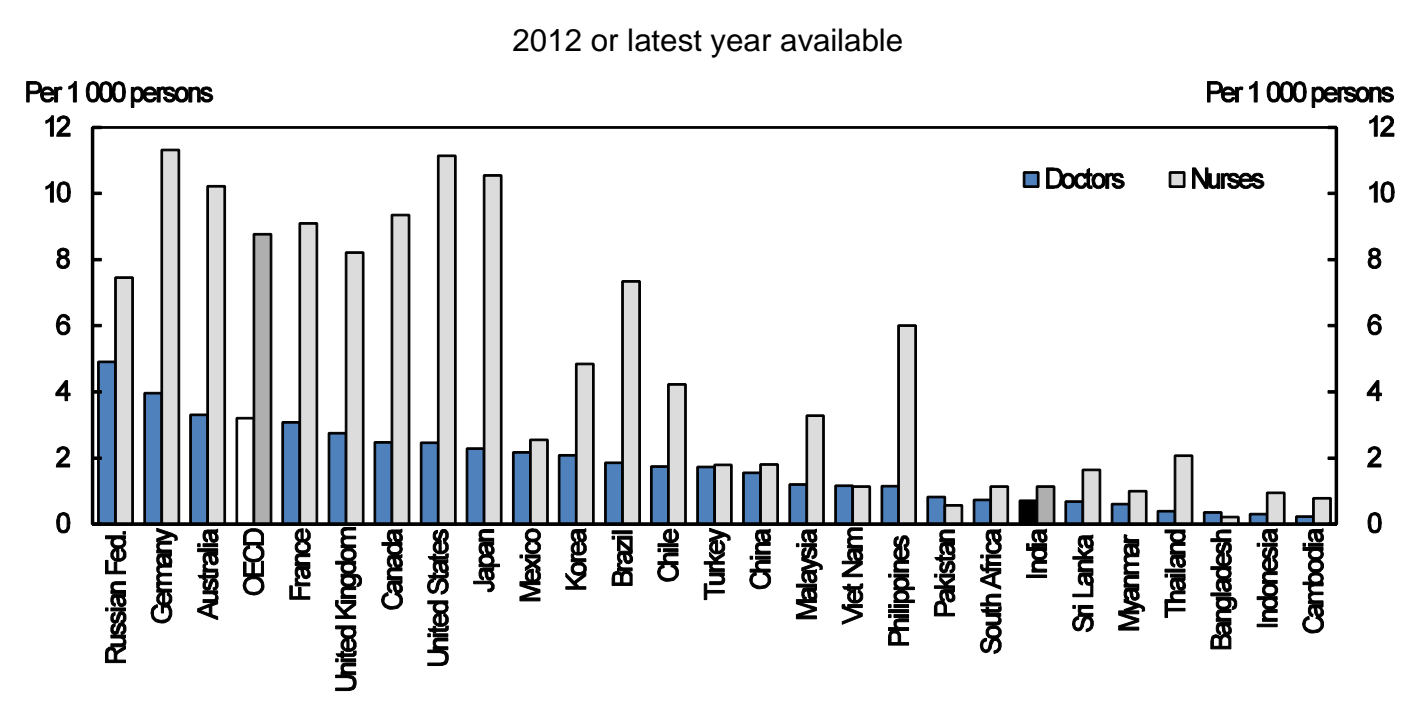

1. The number of doctors and nurses is measured per 1000 persons. For Cambodia, data refer to 2008 and for the Philippines, they refer to 2004. Doctors include physicians qualified in either allopathic medicine or other forms of medicine such as Chinese traditional medicine, ayurveda or homeopathy. Nurses are defined as persons who have completed a programme of basic nursing education and are qualified to provide nursing care.

Source: OECD (2014), Health Database; WHO (2014), Health Systems Database.

Out of pocket payments are an increasingly large share of household budgets, rising from $5 \%$ of household expenditure in 1999-2000 to 11\% in 2004-05 (Ladusingh and Pandey, 2013). Drugs are the biggest component of OOPs, accounting for $72 \%$ of the total (Kumar et al., 2011).Though hospital care accounts for a smaller share of total OOPs, it is more likely to bankrupt the poor. More than one third of patients admitted to hospital are pushed into poverty (Marten et al., 2014). On average, low income households living in rural areas paid $140 \%$ of their annual income in OOPs for a hospital stay compared to 90\% for those in urban areas (Balarajan et al, 2011), the difference being due in large part to lower rural incomes. As a consequence, some $47 \%$ of the cost of hospital admissions in rural areas and $31 \%$ in urban areas were financed by borrowing and the sale of personal goods and assets (Kumar et al., 2011). This financial burden has been one of the key motivations for introducing health care insurance for hospital care for the poor. Although not captured by surveys, informal payments are significant: $20 \%$ of public sector hospital visits are reported to involve informal payments and $12 \%$ involve the use of influence to access health care (Rao et al., 2009).

Public health care spending has been increasing, although from low levels, and is anticipated to continue to do so. Under the previous five year plan, it is estimated to have increased from $0.9 \%$ of GDP in 2007 to $1 \%$ of GDP in 2012, with central government playing a greater role than states. With spending on drinking water, sanitation and meals taken into account, this estimate rises to $1.9 \%$ (Planning Commission, 2012). In the $12^{\text {th }}$ five year plan (2012-17), the central government has indicated it shall seek to raise public spending on health to $2.5 \%$ of GDP.

The cost of achieving the central government's objective of universal coverage for a small number of health services has been estimated to vary between $0.5 \%$ of GDP per year (World Bank, 2013b) and 1\% of GDP per year (Deolalikar, et al., 2008). Some states have increased spending on health, but many of the poorest states have struggled to do so (Box 3). Given the mismatch between states' revenues and their large spending responsibilities, the central government is best positioned to take the lead in funding health care, particularly for the poorest states. 


\section{ECO/WKP(2015)2}

To finance higher public spending on health, India should rely on general taxes, as opposed to social security contributions. Labour based charges that are used to finance health insurance in many OECD and Latin American countries would increase incentives to rely on informal workers - informal employment is already very high in India, and women and ethnic minorities are overrepresented among these workers (OECD, 2010b).

\section{Box 3. The challenge of making health a priority in a decentralised setting}

The financing of health care occurs within the context of considerable federal-state fiscal imbalances. States are responsible for providing health care and sanitation. The central government is responsible for training medical professionals and research. Population control and family planning are a shared responsibility. State governments account for around $60 \%$ of public spending on health but the size of state budgets on health vary widely across states.

Beyond health, states are responsible for other major areas of spending - such as education, irrigation and public utilities - while having limited sources of revenue. On average, states raise about $38 \%$ of total revenues and account for $57 \%$ of total public spending. As a result, around $55 \%$ of states' total expenditure is financed from the central government and loans. States' ability to prioritise is further limited as around $15 \%$ of their spending requires matching funds in order to unlock central grants, a conditionality that exists for major central government health funding programmes.

A combination of accumulated fiscal constraints and differing political priorities between central and state governments has meant that it has been hard to get states to raise their own health spending in the past fifteen years. The World Bank estimated that the elasticity of state government health spending to GDP was 0.94 between 1990-2012. Over the same time, the elasticity of central government health spending to GDP was 1.15, together resulting in general government health spending elasticity of 0.99 .

Source: Rao and Choudhury (2012), World Bank (2013b)

The financial resources devoted to health are very uneven across states. The level of public health spending per capita in Bihar was a sixth of Himachal, the highest spending large state (Table 3). These differences have been increasing in recent years and spending correlates well with income level (Rao and Choudhury, 2012). In all but eight states health spending fell as share of the state total spending between 2000-01 and 2012-13 (RBI, 2013). 
Table 3. Spending on health care, major states and territories

\begin{tabular}{lccc}
\multicolumn{4}{c}{ 2004-0 ${ }^{1}$} \\
\hline & Per capita public (Rs.) & Per capita private (Rs.) & \% of state government spending \\
\hline Himachal Pradesh & 630 & 881 & 5.0 \\
Kerala & 287 & 2,663 & 4.7 \\
Punjab & 247 & 1,112 & 3.0 \\
Karnataka & 233 & 597 & 3.8 \\
Tamil Nadu & 223 & 1,033 & 3.4 \\
Maharashtra & 204 & 1,008 & 2.9 \\
Haryana & 203 & 875 & 3.0 \\
Gujarat & 198 & 755 & 3.1 \\
Andhra Pradesh & 191 & 870 & 3.2 \\
Rajasthan & 186 & 575 & 3.9 \\
Orissa & 183 & 719 & 4.4 \\
West Bengal & 173 & 1,086 & 4.3 \\
Assam & 162 & 612 & 3.1 \\
Madhya Pradesh & 145 & 644 & 3.2 \\
Uttar Pradesh & 128 & 846 & 3.9 \\
Bihar & 93 & 420 & 4.1 \\
\hline
\end{tabular}

1. States are ordered in terms of per capita public spending, in descending order.

Source: MoHFW (2009)

The central government provides financial grants to states to help them meet the cost of running public health services. The largest of these grants is the National Health Mission (NHM), which began in 2005 as the National Rural Health Mission (NRHM), and expanded to include urban areas in mid-2013 (Box 4). It accounts for $60 \%$ of total funding from central government to states for public health and $23 \%$ of total public spending on health at a state level in 2008-09 (MoHFW, 2009). A worthwhile feature of the NRHM is that states have the flexibility to spend funds on their self-identified needs, unlike past conditional grants. NRHM funds can be deployed to hire contractual staff and have focused on introducing new community health workers. The NRHM also includes a large conditional cash transfer programme (the Janani Suraksha Yojana) which provides funds to mothers and community health workers to encourage more institutional births. Alongside the NHM are a range of other conditional grants directed at specific diseases or objectives such as HIV/AIDS, tuberculosis, leprosy, immunisation programmes, child health facilities and the education and training of health professionals.

\section{Box 4. The National Rural Health Mission}

The National Rural Health Mission (NRHM) was established to improve the health of the rural poor. The NRHM sought to improve infrastructure and human resources for health, integrate many separate programmes for disease control (e.g. tuberculosis, HIV/AIDS) into the health system, provide more flexibility for states to meet community needs and increase funding for health care. In terms of outcomes, reducing maternal and infant mortality, reducing malnutrition, reducing anaemia among women and raising the share of women among births were identified as high level goals.

Official statistics show that reductions in maternal and infant mortality have exceeded those achieved prior to the programme introduction, but are still short of the $11^{\text {th }}$ five year Plan targets. Progress towards reducing malnutrition and anaemia are difficult to assess due to shortfalls in data. In terms of infrastructure, there has been an increase in public health care facilities, with the number of sub-centres increasing by $2 \%$, primary health care centres by $6 \%$, community health care centres by $16 \%$ and district hospitals by $45 \%$. Nonetheless, many of these facilities are yet to meet standards in terms of quality, drug supplies and the ability to deliver emergency obstetric care. It is estimated that the gap between staff in facilities and those required was $52 \%$ for midwives and nurses, $76 \%$ for doctors, $88 \%$ for specialists and $58 \%$ for pharmacists. Progress has been made in the important area of child immunisation, where coverage has improved to $61 \%$ by 2009 from $55 \%$ in 2005 .

Source: Planning Commission (2012) and (2011) 
The major injection of public funding provided by the NRHM has not consistently translated into higher levels of health spending. Funds from the NRHM are allocated on a per capita basis, with an additional $30 \%$ provided to 18 'focus states' selected on the basis of life expectancy, infant mortality and family incomes. To receive funding under the NRHM, states have to commit to making a matching contribution of at least $15 \%$ of the central government's allocation, and it is not specified that this needs to be additional funding (Rao and Chaudhary, 2012). Similarly, to receive funding under the new National Urban Health Mission, states have to contribute at least $25 \%$ of the central government's allocation. Studies have shown that many states are too poor to meet co-funding requirements or do not have institutional capacity to absorb additional spending (Berman et al., 2010 and Rao and Choudary, 2012). Shortfalls of up to $35 \%$ have been reported between the funds allocated and paid to states over the last five years, and while states are able to roll unspent funds into subsequent years, some states have been lagging persistently in spending their allocation (CBGA, 2012). Reforms to financing mechanisms are needed to ensure that additional funds from central government translate into measurable expansions in health care services.

\section{Sharpening the states' incentives to deliver critical services}

Allocating health budgets at both central and state levels has traditionally been a 'facility planning' exercise which involves setting aspirational targets of physical buildings and staff based on a ratio of the population (i.e. one community facility per 200000 people). Limited funds have often been spent on what can be procured and not what is most valuable.

As demonstrated in Chile, Mexico and Turkey, a hallmark of the most successful efforts to expand health care coverage across the population has been to specify a 'minimum set' of basic health care services, informed by analysis of which services are the most cost effective relative to a country's health needs (Box 5). There is already considerable research indicating what the highly cost effective services are for India (Chow et al 2007; Deolalikar et al., 2008). These include: fighting against communicable diseases such as malaria, diarrheal diseases and HIV/AIDS; immunising children; promoting institutional births; tuberculosis courses, encouraging condom use; emergency antibiotics, postnatal visit and a range of basic medical counselling and primary care services. In this regard, India's recent Mental Health Bill is a good example of setting high level objectives of expanding care and then allowing for a range of treatment options ranging from hospitals through to community services.

Defining a national 'benefit package' would provide state governments with clear direction on what they ought to prioritise among the range of health services they can provide. As a condition of additional funding, the central government should seek data from states on how many services are delivered rather than how many facilities remain to be constructed. This will require reforming the Health Management Information System and providing more resources to facilities so that they can better enumerate the diagnoses of patients and the services provided.

Central government grants should be designed to encourage states to expand access to services to all citizens. Rather than providing per capita payments, funding should be based on progress in delivering a basic benefit package to everyone in the state. This would involve estimating a baseline level of people who might receive this now, and paying incentives to states that make progress towards this objective. Used successfully in Mexico and Brazil, the virtue of such approaches is that they establish a relationship between actual needs in a state and the level of funding. They would also offer higher prospective financial rewards for those states with poor health coverage and lower prospective rewards for the higher performing states - providing scope to achieve the same objective of fiscal equalisation between states. This would also be a better defence against substitution of state effort than simply surveillance of state budgets, which many OECD countries with significantly more sophisticated fiscal institutions struggle to do. 


\section{Box 5. Financing expansion in health in a federal context: Mexico's Seguro Popular}

The Seguro Popular in Mexico provides one of the most successful examples of expanding health coverage in a federal context. Considerable concern about the impoverishing effects of health costs saw the government increase public funding for health by $1 \%$ of GDP over seven years to provide access to 45 million Mexicans who had not benefitted from the country's existing social health insurance programmes.

The Seguro Popular subsidises access to a package of essential services that grew to 284 in 2012 from 91 interventions in 2004, and covers treatment for more than $95 \%$ of causes in ambulatory units and general hospitals. Even though the Seguro Popular aimed to cover most of the services provided in hospitals, a benefit package was developed. This was critical to properly estimating the resources required in terms of infrastructure, equipment and personnel. It was used as a quality assurance mechanism so that facilities were being held to account for delivering services in line with standard protocols and would not be provided with funding if they could not show they could meet basic standards. Finally, it made people aware of their entitlements from the health care system.

At the time of its introduction, the Seguro Popular was targeted at the self-employed and those in the informal sector. Registering with the Seguro Popular was voluntary, but states had an incentive to register schemes as their budget was based on an annual per family fee and families were given a date to register to avoid co-payments in the future. The Seguro Popular is financed through federal and state governments. Families are also asked to make a modest contribution, with the poorest $20 \%$ of families excluded. Most of the funds $(89 \%)$ are allocated to states to fund the essential package of services, but certain funds are retained centrally to support high cost services (8\%), build health infrastructure and respond to temporary fluctuations in demand (3\%).

Funding to states was largely determined by the number of families registered with the Seguro Popular and was demand driven, though federal-state negotiations helped target funding to specific state needs. States were provided with a financial transfer with two parts: a fixed component (for infrastructure and workforce) and a per person component for people receiving services within an acceptable radius of their home. This funding was often linked to the delivery of essential services such as compulsory vaccinations and basic pharmaceuticals or institutional reforms in states, such as the accreditation of health care facilities.

As a result of the Seguro Popular, Mexico has achieved universal coverage of health care. At the same time as an increase in spending, inequities in the distribution of funding across states have declined substantially. The difference in spending between the state with the largest per capita allocation and the lowest decreased from five to four times. National surveys indicate that the utilisation of 11 highly effective interventions (covering among them child and maternal health, childhood immunisation and the treatment of diarrhoea) has increased. By increasing investment levels to coincide with the registration of families with the Seguro Popular, 751 outpatient clinics and 104 hospitals were built between 2001 and 2006. Prescription drugs delivered in outpatient clinics have risen from $55 \%$ of those prescribed by health workers in 2002 to $89 \%$ in 2006 for clinics serving Seguro Popular enrolees. Care availability has also improved during weekends and evenings in clinics and in emergency services and there are lower waiting times.

Source: Frenk et al (2009), OECD (2005).

\section{Extending the coverage of government-sponsored insurance schemes}

A key policy response to difficulties in expanding services in public hospitals for the poor has been the rise of government sponsored health insurance schemes. They provide incentives to increase access to both public and private hospitals by paying providers on the basis of services delivered. Around 8\% of government health spending is devoted to these schemes (the major schemes are detailed in Table 4). Although they are called 'insurance', these schemes are in essence a payment system, with contributions paid by governments to private insurance companies to reimburse patients care.

Government-sponsored insurance schemes have come to cover a fifth of the population. Around $20 \%$ of the population was covered in 2010, reflecting enormous growth since 2003-04 when such schemes had only $3 \%$ of population. Efforts have been made to provide wider access to Employees' State Insurance (ESI) beneficiaries - organised private sector employees, with earnings below a certain threshold, and their dependents - in the general system. In particular, the wage ceiling has been hiked. Also, some efforts have been made to provide access to non-ESI beneficiaries at the under-utilised ESI hospitals. Still, much of the growth in coverage has been driven by the Rashtriya Swasthya Bima Yojana (RSBY) targeted at those below poverty line. 
The RSBY has many attractive features (Box 6). However, it could be improved. The number of claims remains low as awareness of its reimbursements for health costs is low. An evaluation recently carried out by the Ministry of Labour and Employment in three states revealed that only $32 \%$ of the enrolled households were given a list of hospitals and only $13 \%$ were given information as to how the card had to be used (Ministry of Labour and Employment, 2013). Because of poor awareness and low frequency of hospitalisations, the effect of these schemes in significantly reducing out-of-pocket or catastrophic health care spending remains to be seen (Selvaraj and Karan, 2012). Current pilot campaigns to improve patient awareness and educated people of the benefits available to them should be extended.

\section{Box 6. The RSBY facilitates access to hospital care for the poor}

The Rashtriya Swasthya Bima Yojana (RSBY) was created in 2008 to provide the poor and informal sector workers with better access to hospital care. It gives users a choice across private and public hospitals, creates incentives for public providers to increase volumes of care and for private insurers to extend coverage rapidly.

\section{Coverage and funding}

The RSBY targets Below Poverty Line (BPL) families. As of May 2014, the RSBY operated in 479 (with full enrolment in 436) out of the 680 districts. It covered 37 million families, out of the 69 million BPL families in India, though with large variation in coverage across states, ranging from $38 \%$ of BPL families in Uttarakhand to $85 \%$ in Kerala (RSBY website). It reimburses spending up to INR 30000 (USD 485) for a family of five per year.

Insurance premiums are paid by governments to private insurance companies which reimburse hospital care. With the premium paid for each household enrolled, insurers have an incentive to enroll as many households as possible from the beneficiary list. Individuals pay only a nominal cost (INR 30 or USD 67 cents) associated with the receipt of a smart card. The central government funds $75 \%$ of premiums under the RSBY, and states contribute the balance. For North Eastern states which are poorer, the central government contribution can be raised to $90 \%$.

\section{The technology reduces fraud and can be used for other social benefits}

The biometric-enabled smart cards issued by the RSBY programme verify and authorise the identity of beneficiaries. RSBY smart cards provide a cash- and paper-less way of claiming benefits - all claims are processed and paid electronically. The RSBY information and technology infrastructure is thus less prone to abuse and corruption than other approaches to distribute social benefits. It is increasingly used as a platform for distributing other social benefits, with pilot schemes for some subsidies launched in some areas to minimise leakages (e.g. the National Social Assistance Programme in Jharkhand and the food and kerosene subsidy in Chhattisgarh).

\section{Portability of benefits, user choice and provider efficiency}

The RSBY smart cards can be used in any accredited hospital, public or private, across the country - 6093 private hospitals and 4218 public as of May 2014. The RSBY thus introduces some level of competition among providers. With hospitals paid on a per case basis, the RSBY also creates incentives to increase the volume of activity. The number of cases treated by public hospitals has increased steadily, from 5\% of the total in 2008 to $40 \%$ in 2013.

\section{Empowering women through the RSBY}

The state of West Bengal has made it mandatory for the women to be head of families for the RSBY as a mean to empower women - in other states the practice is to issue the RSBY smart cards with men as heads of families.

\section{Top-up schemes and other schemes provided by individual states}

A few states have introduced top-up insurance schemes to complement the RSBY either by reimbursing more services or by covering more people. As an example, the states of Chhattisgarh, Kerala and Meghalaya have extended the coverage to all families with the extra premium fully born by them. Himachal Pradesh extended the package value to INR 175000 .

The states of Andhra Pradesh and Tamil Nadu have developed their own government-sponsored insurance scheme which are more generous in benefits and provide financial protection to nearly $80 \%$ and $50 \%$ of their populations respectively. 
ECO/WKP(2015)2

Table 4 Major government-sponsored health insurance schemes: eligibility and coverage

\begin{tabular}{|c|c|c|c|c|c|}
\hline Scheme & Coverage & Eligibility & $\begin{array}{l}\text { Spending (INR } \\
\text { millions) and } \\
\text { source }\end{array}$ & $\begin{array}{l}\text { Hospitalisation } \\
\text { frequency }\end{array}$ & $\begin{array}{l}\text { Limits in } \\
\text { coverage } \\
\text { (annual) }\end{array}$ \\
\hline \multicolumn{6}{|c|}{ Central Government Schemes } \\
\hline $\begin{array}{l}\text { Employees State } \\
\text { Insurance } \\
\text { (ESI)Scheme }\end{array}$ & 55 million & $\begin{array}{l}\text { Workers from the } \\
\text { private organised } \\
\text { sector }\end{array}$ & $\begin{array}{l}\text { 19,900 (employer } \\
\text { and employee wage } \\
\text { contributions) }\end{array}$ & $\begin{array}{l}0.75 \% \text { per } \\
\text { member per } \\
\text { year }\end{array}$ & None \\
\hline $\begin{array}{l}\text { Central Government } \\
\text { Health Scheme }\end{array}$ & 3 million & $\begin{array}{l}\text { Employees and } \\
\text { pensioners of } \\
\text { central government }\end{array}$ & $\begin{array}{l}16000 \text { (central } \\
\text { government budget } \\
\text { and contributions) }\end{array}$ & $\mathrm{n} / \mathrm{a}$ & None \\
\hline $\begin{array}{l}\text { Rashtriya Swasthya } \\
\text { Bima Yojana (RSBY) }\end{array}$ & $\begin{array}{l}37.5 \text { million } \\
\text { families }\end{array}$ & $\begin{array}{l}\text { Below poverty line } \\
\text { families }\end{array}$ & $\begin{array}{c}3500 \text { (75\% central, } \\
25 \% \text { state) }\end{array}$ & $\begin{array}{l}2.5 \% \text { per } \\
\text { beneficiary }\end{array}$ & $\begin{array}{l}\text { INR 30,000 per } \\
\text { family }\end{array}$ \\
\hline \multicolumn{6}{|c|}{ State Government Schemes } \\
\hline $\begin{array}{l}\text { Andhra Pradesh } \\
\text { (Aarogyasri) }\end{array}$ & $\begin{array}{l}20.4 \text { million } \\
\text { families } \\
\text { (70 million } \\
\text { beneficiaries) }\end{array}$ & $\begin{array}{c}\text { Below poverty line } \\
\text { or annual income } \\
\text { less than INR } \\
75000\end{array}$ & $\begin{array}{c}12,000(100 \% \\
\text { state })\end{array}$ & $\begin{array}{l}0.6 \% \text { per } \\
\text { beneficiary }\end{array}$ & $\begin{array}{l}\text { INR } 150,000 \text { per } \\
\text { family }\end{array}$ \\
\hline $\begin{array}{l}\text { Tamil Nadu } \\
\text { (Kalaignar) }\end{array}$ & $\begin{array}{l}13.4 \text { million } \\
\text { families } \\
\text { (36 million } \\
\text { beneficiaries) }\end{array}$ & $\begin{array}{c}\text { Below poverty line } \\
\text { or annual family } \\
\text { income below INR } \\
72000\end{array}$ & $5,170(100 \%$ state $)$ & $0.5 \%$ annualised & $\begin{array}{l}\text { INR } 100,000 \\
\text { over four years }\end{array}$ \\
\hline $\begin{array}{l}\text { Karnataka } \\
\text { (Yeshasvini) }\end{array}$ & 3 million & $\begin{array}{l}\text { Members of rural } \\
\text { cooperative } \\
\text { societies }\end{array}$ & $550(100 \%$ state $)$ & $\mathrm{n} / \mathrm{a}$ & $\begin{array}{l}\text { INR } 200,000 \text { per } \\
\text { person }\end{array}$ \\
\hline
\end{tabular}

Source: La Forgia and Nagpal, 2012 and RSBY website.

Districts with a higher share of socioeconomically disadvantaged groups are less likely to participate in the RSBY and their enrolment rate is lower (Nandi et al., 2013). Identifying families living below poverty line (BPL) families is also a crude process, an issue affecting a number of social schemes. The process of rolling out the RSBY has helped to remove those who are no longer poor from BPL rolls (Fan, 2013). One key challenge however for the RSBY is to cover poor households that have been overlooked in the BPL census. The recent decision to extend the RSBY to include non-BPL but socioeconomically disadvantaged groups, such as domestic workers, is a step in the right direction. Care should also be taken to contain administrative costs. Experience in OECD countries reveals that administrative costs tend to be higher in those countries relying most on multiple payers and private insurance companies (OECD, 2010c).

Health insurance schemes should ideally fund primary health care services irrespective of whether this is delivered by a qualified doctor working privately or in a public clinic, because this is where the biggest health gains lie. It has been argued that the current focus on hospital care may fuel higher salaries in the hospital sector and make it harder to attract doctors into community health facilities (HLEG, 2011). The expansion of health insurance to cover primary health care services, as foreshadowed in the government's latest five-year plan (Planning Commission, 2012), can help direct funds to primary care. One option would be to extend payments from insurance to supplementing the existing operational budgets of community primary health care facilities. Funding linked to the number of services delivered would provide an incentive to improve availability and support many under-funded clinics. In gradually rolling out such an approach, priority should be given on areas of greatest need (rural communities and urban slums). 
A focus on quality and incentives for employees in public clinics ought to accompany an extension of insurance payments. Just as the RSBY currently 'empanels' private sector hospitals as meeting certain financial and quality safeguards, government-run primary health care clinics should have to meet basic quality criteria (such as the cleanliness of facilities, appropriate qualifications of staff and the availability of essential supplies) to be 'empanelled' to receive reimbursements on the basis of services they provide. To reward higher levels of service provision, states ought to allow for a share of case-based payments to flow through to employees, as a supplement to their current public sector wages.

Finally, getting the most out of the rapid growth of expanded health insurance requires better coordination between the ministries of Health and Labour. The Health Ministry has been investing and bolstering government-run primary health care services, while the Labour Ministry is subsidising private and public hospital care. Coordination to ensure both of these efforts are mutually reinforcing is poor at central and state levels. Currently, state governments can negotiate their key policy objectives with central government for the National Health Mission. State governments ought to also have some flexibility to negotiate which services they choose to finance through the insurance schemes. This will allow states to customise how they can leverage the potential of schemes - use the private sector - to complement their efforts in improving public health care services. As long as states are held to account for the delivery of critical services to all patients, policy should support the mix of public and private that a state chooses to expand access to care.

\section{Recommendations to improve health outcomes for all}

\section{Key recommendations}

- Increase public spending on health care with particular focus on preventive and primary care, especially to rural areas and urban slums.

- $\quad$ Expand the number of health professionals and up-skill professionals located in rural areas.

- Strengthen the management of public health care facilities and ensure that private facilities and their employees meet minimum quality standards.

\section{Further recommendations}

- Undertake further preventive measures to improve health, such as improving sanitation, access to clean water, and road safety; raising immunisation rates; increasing taxes on tobacco; reducing salt intake; and improving sexual education.

- Reduce geographical disparity in access to health care by locating more medical colleges in northern and poorer states.

- Improve the labour market conditions of nurses through fewer short term contracts and opportunities to undertake further education.

- $\quad$ Specify a package of critical services which should be available to all and reform both public grants and insurance support to states to incentivise the delivery of these services.

- Gradually extend government-sponsored health insurance to primary care, beginning with deprived communities, in particular in rural areas and urban slums. Improve awareness of reimbursements for care available through insurance schemes.

- Improve the prescribing of pharmaceuticals by actively training health workers. Introduce a transparent drug procurement process to improve the availability of drugs in public facilities. 


\section{BIBLIOGRAPHY}

Banerjee, A. and E. Duflo (2009), 'Improving Health Care Delivery in India', Paper prepared for the Deaton Festshrift Conference, September http://economics.mit.edu/files/5172

Banerjee, A., A. Deaton and E. Duflo (2004), "Wealth, Health and Health Services in Rural Rajasthan", American Economic Review, Vol, 94, No. 2, pp. 326-330

Balarajan, Y., S. Selvaraj and S. Suramanian, (2011), Health care and equity in India, Lancet, 377; 505-15

Berman, P., R. Ahuja, A. Tandon, S. Sparkes, and P. Gottret, (2010), "Government Health Financing in India: Challenges in Achieving Ambitious Goals", Health, Nutrition and Population Discussion Paper, World Bank, Washington, DC.

https://openknowledge.worldbank.org/handle/10986/13597

Bhaumik S. (2013), "Why Is India Short of Nurses and What Can We Do about It?" Workforce Planning (Feature), BMJ 3;346:f4024 (June 2013).

CBGA (2012), "National Rural Health Mission” Budgeting for Change Series 2011, Centre for Budget Governance and Accountability and UNICEF, March.

Chaudhury R., R. Parameswar, U. Gupta, S. Sharma, U. Tekur and J. Bapna (2005). "Quality medicines for the poor: experience of the Delhi programme on rational use of drugs." Health Policy Plan. 20(2): 124-136.

Chandra, S. (2012), 'Status of Indian Medicine and Folk Healing: With a Focus on Integration of AYUSH Medical Systems in Healthcare Delivery', Аyu. 33(4):461-5, October.

Chow, J., S. Darley and R. Laxminarayan (2007), "Cost Effectiveness of Disease Interventions in India", Resources for the Future Discussion Paper, RFF DP 07-53, December.

Das, B., C. Sarkar and A. Majumder (2006). "Medication use for pediatric upper respiratory tract infections." Fundam Clin Pharmacol 20(4): 385-90, August.

Das, J., A. Holla, V. Das, M. Mohanan, D. Tabak and B. Chan (2012), "In Urban and Rural India, a Standardized Patient Study Showed Low Levels of Provider Training and Huge Quality Gaps", Health Affairs 31(12):2774-84, December.

Deolalikar, A., D. Jamison, P. Jha, R. Laxminarayan, "Financing Health Improvements in India", Health Affairs. Jul-Aug; 27(4):978-90.

DLHS (2006), Reproductive and Child Health, District Level Household Survey 2002-04, International Institute for Population Sciences and Government of India, August. 
Drèze, J. and A. Sen (2013), An Uncertain Glory - India and its Contradictions, Princeton Press.

Fan, V. (2013), “The Early Success of India's Health Insurance for the Poor”, Center for Global Development Essay, RSBY, June.

www.cgdev.org/sites/default/files/archive/doc/full_text/CGDEssays/3120468/early-success-indiashealth-insurance-rsby.html

Frenk, J., O. Gómez-Dantés and F. Knaul (2009), "The democratisation of health in Mexico: financial innovations for universal coverage", Bulletin of the World Health Organization, 87(7): 542-548, July. doi: 10.2471/BLT.08.053199

Fujisawa, R. and G. Lafortune (2008), "The Remuneration of General Practitioners and Specialists in 14 OECD Countries: What are the Factors Influencing Variations across Countries?" OECD Health Working Papers, No. 41, OECD Publishing, Paris. doi: $10.1787 / 228632341330$

HLEG (2011), High Level Expert Group Report on Universal Health Coverage for India, Instituted by the Planning Commission of India, New Delhi

Institute for Health Metrics and Evaulation, IHME (2013), Global Burden of Disease 2010, Released March 2013, www.healthmetricsandevaluation.org/gbd

Jack, W. and M. Lewis (2009), 'Health Investments and Economic Growth: Macroeconomic Evidence and Microeconomic Foundations', in Spence, M. and Lewis, M. (2009), Health and Growth, Commission on Growth and Development, World Bank publishing

Kotwani, A (2010). "Access to Essential Medicines and Standard Treatment for Chronic Diseases" Editorial- Indian J Pharmacol 42(3): 127-8.

Kripalani, M. (2008). Indian Pharma: Hooked on the Hard Sell. "BusinessWeek" webpage, March, http://www.businessweek.com/stories/2008-03-25/indian-pharma-hooked-on-the-hardsellbusinessweek-business-news-stock-market-and-financial-advice

Kumar, A., L. Chen, M. Choudhury, S. Ganju, V. Mahajan, A. Sinha and S. Abhijit (2011), "Financing Health Care for All: Challenges and Opportunities", Lancet, 377: 668-79

Ladusingh, L. and A. Pandey (2013), "The High Cost of Dying', Economic and Political Weekly, Vol XLVIII No. 11, March.

La Forgia, G. and S. Nagpal (2012), Government-Sponsored Health Insurance in India: Are You Covered? World Bank, August.

Lopez-Casanovas, G., B. Rivera and L. Currais (2005), Health and Economic Growth: Findings and Policy Implications, MIT Press

Lunt, N., R. Smith, M. Exworthy, S. Green, D. Horsfall and R. Mannion (2010), "Medical Tourism: Treatments, Markets and Health System Implications: a Scoping Review”, OECD Publishing, Paris http://www.oecd.org/els/health-systems/48723982.pdf,

Malik, G. (2008), "Nursing Crisis in India”, Journal of Health and Development, Vol. 4, No. 1 - 4. 
Marten R., D. McIntyre, C. Travassos, S. Shishkin, W. Longde, S. Reddy, J. Vega (2014), “An assessment of progress towards universal health coverage in Brazil, Russia, India, China, and South Africa (BRICS)", The Lancet, 30 April 2014.

MoHFW (2009), National Health Accounts India, 2004-05, National Health Accounts Cell, Ministry of Health and Family Welfare, Government of India.

MoHFW (2012), Rural Health Statistics in India 2012, Statistics Division, Ministry of Health and Family Welfare, Government of India, March.

MOSPI (2013), Statistical Year Book, India, Ministry of Statistics and Programme Implementation, Government of India, New Delhi.

Muraleedharan, V.R., U. Dash and L. Gilson (2013), “Tamil Nadu 1980s-2005: A Success Story in India”, Chapter 6 in Good Health at Low Cost, 25 years on, London School of Hygiene and Tropical Medicine, http://ghlc.lshtm.ac.uk/

Nandi, A., A. Ashok and R. Laxminarayan (2013), 'The Socioeconomic and Institutional Determinants of Participation in India's Health Insurance Scheme for the Poor', PLOS One, June.

Nandraj S, V. Muraleedharan, V. Baru, I. Qadeer and R. Priya (2001),“Private Health Sector in India: Review and Annotated Bibliography", http://www.cehat.org/publications/PDf\%20files/r20a.pdf

Narayan, S, P. Narayan, and S. Mishra (2010), "Investigating the Relationship between Health and Economic Growth: Empirical Evidence from a Panel of 5 Asian Countries", Journal of Asian Economics, Vol. 21(4), pages 404-411, August.

NCHM (2005), Report of the National Commission on Macroeconomics and Health, Ministry of Health and Family Welfare, Government of India.

National Sample Survey Organisation, NSSO (2006) "Morbidity and Health Care and Condition of the Aged 2004-05", New Delhi: National Sample Survey Organisation, Ministry of Statistics and Programme Implementation, Government of India.

NPPA (2002). "Pharmaceutical Policy - 2002" Department of Chemicals and Fertilizers, Government of India.

OECD (2005), OECD Reviews of Health Systems: Mexico 2005, OECD Publishing, Paris. doi: $10.1787 / 9789264008939$-en

OECD (2007), "Immigrant Health Workers in OECD Countries in the Broader Context of Highly Skilled Migration", in OECD, International Migration Outlook 2007, OECD Publishing, Paris. doi: 10.1787/migr_outlook-2007-5-en

OECD (2010a), Nurses in Advanced Roles: A Description and Evaluation of Experiences in 12 Developed Countries', OECD Health Working Papers, No. 54, OECD Publishing, Paris. doi: $10.1787 / 5 \mathrm{kmbrcfms} 5 \mathrm{~g} 7$-en

OECD (2010b), Economic Policy Reforms 2010: Going for Growth, OECD Publishing, Paris. doi: 10.1787/growth-2010-en 
OECD (2010c), Health Care Systems: Efficiency and Policy Settings, OECD Publishing, Paris. doi: 10.1787/9789264094901-en

OECD (2012a), Health at a Glance: Asia/Pacific 2012, OECD Publishing, Paris. doi: 10.1787/9789264183902-en

OECD (2013), OECD Health Statistics 2013, Online database, OECD Publishing, Paris. doi: $10.1787 /$ health-data-en

Ono, T., M. Schoenstein and J. Buchan (2014), "Geographic Imbalances in Doctor Supply and Policy Responses", OECD Health Working Papers, No. 69, OECD Publishing, Paris. doi: $10.1787 / 5 j z 5$ sq51s1wl-en

Patel, V., S. Chatterji, D. Chisholm, S. Ebrahim, G. Gopalakrishna, C. Mathers, V. Mohan, D. Prabhakaran, R. Ravindran and K.Reddy. (2011), "Chronic diseases and injuries in India", Lancet, 377(9763): 413-28, January.

http://www.ncbi.nlm.nih.gov/pubmed/21227486

Percot, M. (2006), 'Indian Nurses in the Gulf: Two Generations of Future Migration', South Asia Research, Vol. 26 no. 1 41-62, February.

Planning Commission (2012), Twelevth Five Year Plan 2012-12, Vol. III, Planning Commission, Government of India, New Delhi.

Raha, S., P. Berman and A. Bhatnagar,(2009), "Career Preferences of Medical and Nursing Students in Uttar Pradesh", India Health Beat, World Bank and Public Health Foundation of India, Washington, $\mathrm{DC}$

Rao, K., A. Bhatnagar, P. Berman, I. Saran and S. Raha (2008), "India's Health Workforce, Size, Composition and Distribution", Human Resources for Health Technical Report \#1, World Bank and Public Health Foundation of India http://www.hrhindia.org/assets/images/Paper-I.pdf

Rao, K., I. Saran and A. Srivastava (2009), 'The Inequity of Informal Payments for Health Care in India', India Health Beat, Vol. 2, No.1, World Bank/Public Health Foundation of India

Rao, M., K. Rao, A. Kumar, M. Chatterjee and V. Sundararaman (2011), "Human Resources for Health in India”, Lancet, Vol. 377, Issue 9765, Pages 587 - 598, February.

Rao, K., A. Bhatnagar and P. Berman (2012), "So many, yet few: Human resources for health in India', Human Resources for Health 2012, 10:19.

Rao, M. and M. Choudhury (2012), "Health Care Financing Reforms in India", Working Papers 12/100, National Institute of Public Finance and Policy.

Ray K., S. Mukhopadhyay, D. Dutt, P. Chatterjee, P. Roychowdhury, K.Roy, and S. Banerjee (2003). "Cross-sectional study of consumption, compliance and awareness about antibiotic utilisation amongst the urban community in Kolkata." J Indian Med Assoc 101(1): 7, 9-10.

Roy N., N. Madhiwalla and S. Pai (2007). "Drug promotional practices in Mumbai: a qualitative study." Indian Journal of Medical Ethics 4(2):57-61. 
RBI (2013), State Finances: A Study of Budgets of 2012-13, Reserve Bank of India, January.

RSBY (2013), Scheme Status, available at: http://www.rsby.gov.in/Overview.aspx.

Sachan, D. (2013), “Tackling corruption in Indian Medicine”, Lancet, Vol. 382, Issue 9905, Pages e23 e24, November.

Selvaraj S. and A.K. Karan (2012), "Why publicly financed health insurance schemes are ineffective in providing financial risk protection", Economic \& Political Weekly, Vol. 47, No. 11, pp. 60-68.

Shepherd-Smith A. (2012), "Free drugs for India's poor", Lancet Vol. 380, September. http://ac.els-cdn.com/S0140673612614895/1-s2.0-S0140673612614895-main.pdf?_tid=b63a4904b37e-11e3-b5ea-00000aab0f02\&acdnat=1395684435_1725a97500277e12f593fe55ff263939

Spears, D. and S. Lamba (2013), 'Effects of Early-Life Exposure to Sanitation on Childhood Cognitive Skills: Evidence from India's Total Sanitation Campaign', Policy Research Working Paper 6659, World Bank Sustainable Development Network, World Bank Publishing

Spence, M. and M. Lewis (2009), Health and Growth, Commission on Growth and Development, World Bank publishing

Sudarshan, H. and N.S. Prashanth (2011), "Good Governance in Health Care: the Karnataka Experience", Lancet, Vol. 377, pages 791 \& 792, March.

World Bank (2013a), World Development Indicators, World Bank

World Bank (2013b), 'India Development Update, April 2013', Washington, DC., World Bank. https://openknowledge.worldbank.org/handle/10986/16542

WHO (2012), Global Health Observatory Data Repository.

WHO/HAI (2006). Price, availability and affordability: an international comparison of chronic disease medicines. Geneva, Health Action International.WHO/UNICEF (2012), Progress on Sanitation and Drinking Water: Joint Monitoring Programme update 2012 


\section{WORKING PAPERS}

The full series of Economics Department Working Papers can be consulted at www.oecd.org/eco/workingpapers

1183. Challenges and opportunities of India's manufacturing sector

(January 2015) by Isabelle Joumard, Urban Sila and Hermes Morgavi

1182. The heterogeneity of product market regulations

(December 2014) by Jean-Marc Fournier

1181. Implicit regulatory barriers in the EU single market: new empirical evidence from gravity models

(December 2014) by Jean-Marc Fournier, Aurore Domps, Yaëlle Gorin, Xavier Guillet and Délia Morchoisne

1180. Can pro-growth policies lift all boats? An analysis based on household disposable income (December 2014) by Orsetta Causa, Alain de Serres and Nicolas Ruiz

1179. Empirical evidence on the effects of environmental policy stringency on productivity growth (December 2014) by Silvia Albrizio, Tomasz Koźluk and Vera Zipperer

1178. The Indicators of the Economic Burdens of Environmental Policy Design - Results from the OECD Questionnaire

(December 2014) by Tomasz Koźluk

1177. Measuring Environmental Policy Stringency in OECD Countries-A Composite Index Approach (December 2014) by Enrico Botta and Tomasz Koźluk

1176. Do Environmental Policies Matter for Productivity Growth? Insights from new Cross-Country Measures of Environmental Policies

(December 2014) by Silvia Albrizio, Enrico Botta, Tomasz Koźluk and Vera Zipperer

1175. Making economic growth more socially inclusive

(December 2014) by Andrés Fuentes Hutfilter and Andreas Kappeler

1174. New tax and expenditure elasticity estimates for EU budget surveillance

(December 2014) by Robert W.R. Price, Thai-Thanh Dang and Yvan Guillemette

1173. Moving towards a more dynamic business sector in Spain

(November 2014) by Alberto Gonzalez Pandiella

1172. Better harnessing talent and knowledge to boost sustainable medium-growth in Spain (November 2014) by David Haugh and Ben Westmore

1171. The internet economy - regulatory challenges and practices

(November 2014) by Isabell Koske, Rosamaria Bitetti, Isabelle Wanner and Ewan Sutherland

1170. A revival of the private rental sector of the housing market? Lessons from Germany, Finland, the Czech Republic and the Netherlands

(October 2014) by Rik de Boer and Rosamaria Bitetti 
1169. Secular stagnation: evidence and implications for economic policy

(October 2014) by Łukasz Rawdanowicz, Romain Bouis, Kei-Ichiro Inaba and

Ane Kathrine Christensen

1168. Investment gaps after the crisis

(October 2014) by Christine Lewis, Nigel Pain, Jan Strasky and Fusako Menkyna

1167. Factors behind the decline in real long-term government bond yield

(October 2014) by Romain Bouis, Kei-Ichiro Inaba, Łukasz Rawdanowicz and

Ane Kathrine Christensen

1166. The effect of the global financial crisis on the OECD potential output

(October 2014) by Patrice Ollivaud and David Turner

1165. Determinants of households' investment in energy efficiency and renewables - evidence from the OECD Survey on household environmental behaviour and attitudes

(October 2014) by Nadia Ameli and Nicola Brandt

1164. Addressing high household debt in Korea

(September 2014) by Randall S. Jones and Myungkyoo Kim

1163. Reducing the high rate of poverty among the elderly in Korea

(September 2014) by Randall S. Jones and Satoshi Urasawa

1162. Promoting the financing of SMEs and start-ups in Korea

(September 2014) by Randall S. Jones and Myungkyoo Kim

1161. Fostering inclusive growth by promoting structural change in the business sector

(September 2014) by Rauf Gönenç, Oliver Röhn, Vincent Koen and Fethi Öğünç

1160. Reducing macroeconomic imbalances in Turkey

(September 2014) by Oliver Röhn, Rauf Gönenç, Vincent Koen and Evren Erdoğan Coşar

1159. Reinvigorating the EU Single Market

(September 2014) by Jean-Marc Fournier.

1158. An exploration of the determinants of the subjective well-being of Americans during the great recession

(August 2014) by Aida Caldera Sánchez and Caroline Tassot.

1157. Boosting the development of efficient SMEs in the Netherlands (September) by Rafał Kierzenkowski and Jochebed Kastaneer

1156. Making the banking sector more resilient and reducing household debt in the Netherlands (September 2014) by Rafał Kierzenkowski, Olena Havrylchyk and Pierre Beynet

1155. US long term interest rates and capital flows to emerging economies

(July 2014) by Eduardo Olaberria

1154. Productivity measurement with natural capital and bad outputs

(July 2014) by Nicola Brandt, Paul Schreyer and Vera Zipperer 